\title{
Уникальные гематитовые жилы Терского побережья, Кольский регион: состав, структурно-текстурные особенности и генезис
}

\author{
Зозуля Д.Р. ${ }^{1}$, Соловьева А.Н. ${ }^{2}$, Чикирёв И.В. ${ }^{1,3}$ \\ ${ }^{1}$ Геологический институт КНЦ РАН, Anamumbl, zozulya@geoksc.apatity.ru \\ ${ }^{2}$ УАиМ ФИЦ КНЦ РАН, Anamumbl, annaivanova2019@mail.ru \\ ${ }_{3}^{3}$ Апатитский филиал Мурманского ГТУ, Anатить, chikireviv@mstu.edu.ru
}

Аннотация. В статье приведены данные минерального состава и структурно-текстурных особенностей анхимономинеральных гематитовых жил в песчаниках терской свиты, недавно открытых авторами в районе мыса Корабль, Кольский п-ов. Жилы состоят из мелкокристаллического пластинчатого гематита с незначительной примесью кварца и микроклина. Характер взаимоотношения с вмещающими породами, околожильных изменений и структурных особенностей позволяют предполагать образование жил из гидротермальных растворов, аккумулировавших железистое вещество из песчаников на стадии тектонотермальной позднепалеозойской активизации восточной части Балтийского щита. По нашим данным, изученные гематитовые жилы являются новым вещественно-генетическим типом гидротермальных жильных образований.

Ключевые слова: гематит; гидротермальная жила; песчаник; Терский берег.

\section{Unique hematite veins of Tersky Coast, Kola region: composition, structural-textural features and genesis}

\author{
Zozulya D.R. ${ }^{1}$, Solovjova A.N. ${ }^{2}$, Chikiryov I.V. ${ }^{1,3}$ \\ ${ }^{1}$ Geological Institute KSC RAS, Apatity, zozulya@geoksc.apatity.ru \\ ${ }^{2}$ Department of Postgraduate Studies, KSC RAS, Apatity, annaivanova2019@mail.ru \\ ${ }^{3}$ Apatity Branch, Murmansk State Technical University, Apatity, chikireviv@mstu.edu.ru
}

\begin{abstract}
The article presents data on the mineral composition and structural and textural features of anchimonomineral hematite veins in the sandstones of the Terskaya Formation, recently discovered by the authors in the area of Cape Korabl', Kola Peninsula. The veins are composed of fine-grained lamellar hematite with minor amounts of quartz and microcline. The relationship with the host rocks, their alteration and structural features of veins suggest the formation of veins from hydrothermal solutions that accumulated ferruginous matter from sandstones at the stage of tectonothermal Late Paleozoic activation of the Eastern part of Baltic shield. According to our data, the studied hematite veins are a new material-genetic type of hydrothermal vein formations.
\end{abstract}

Key words: hematite; hydrothermal vein; sandstone; Tersky Coast.

\section{Введение}

Гидротермальные месторождения образуются за счет циркуляции горячих минерализованных рудоносных растворов магматического или иного происхождения. Возникновение их происходило на протяжении всей истории развития Земли (от архея до наших дней). Одной из самых распространенных форм гидротермальных тел являются жилы. Жильные тела образуют ограниченные по площади и объему поля распространения.

Несмотря на то, что полезные ископаемые, связанные с гидротермальными жилами, были предметом активной эксплуатации человеком на протяжении нескольких тысячелетий, многие из них и в настоящее время имеют экономическое значение (месторождения вольфрама, олова, золота, урана, кобальта, серебра, декоративных и коллекционных минералов, др.).

В то время как баритовые и кварцевые (в том числе аметистовые) жилы в песчаниках терской свиты были и ранее хорошо известны в этом районе Терского побережья, то мономинеральные гематитовые жилы были обнаружены впервые совсем недавно. Уникальность последних находится не только в их необычном составе, но и в том, что такие жилы в мире ранее были не известны. Данная работа направлена на изучение необычных процессов переноса и аккумуляции металлов в ходе низкотемпературных/гидротермальных процессов. 


\section{Литология терской свиты; геологическая позиция жил}

Породы терской свиты распространены вдоль Терского побережья Кольского региона. Отложения свиты представлены аркозовыми песчаниками, алевролитами и аргиллитами, кроме того, встречаются отдельные линзы гравелитов и конгломератов полимиктового состава. Породы свиты имеют характерный красно-коричневый цвет за счет развития гематитового пленочного цемента вокруг зерен кварца. В целом для толщи характерно линзовидное строение. Различные литотипы пород (аргиллиты, алевролиты, песчаники) образуют линзы протяженностью 50-100 м при мощности до 3 м. Толща залегает субгоризонтально с незначительным падением (5-10 градусов) слоев в южном направлении. Мощность пород свиты составляет около 500 м.

Для отложений свиты характерны различные осадочные текстуры - симметричная рябь волнения, трещины усыхания, косослоистые серии, свидетельствующие о мелководных условиях их формирования. Резкая фациальная изменчивость пород терской свиты, выражающаяся в уменьшении фаций алевролитов и аргиллитов в западном направлении, также является показателем мелководного генезиса пород свиты.

По комплексу микрофоссилий Б.В. Тимофеев относит отложения терской свиты к среднему рифею (Сергеева и др., 1974). Определение изотопного возраста, выполненного калийаргоновым методом для двух образцов алевролитов из отложений терской свиты, дали значения 1263 +/- 40 млн. лет и 1080 +/- 40 млн. лет (Любцов и др., 1989), что также подтверждает среднерифейский возраст.

Отложения терской свиты слагают северный борт кандалакшского авлакогена, заложение и развитие которого происходило в течение рифея. По своим структурно-текстурным и литологическим характеристикам породы терской свиты хорошо коррелируются с другими рифейскими отложениями авлакогенов, широко распространенных на Восточно-Европейской платформе. Вероятнее всего в позднепалеозойское время породы терской свиты испытали тектонотермальную активизацию.

Гематитовые жилы были обнаружены в приливно-отливной зоне в районе мыса Корабль (рис. 1). Куст состоит из нескольких субпараллельных жил мощностью 10-20 см и протяженностью до первых десятков метров. Жилы имеют субширотное простирание и вертикальное падение. В этом же районе развиты зоны гидротермальной / метасоматической проработки шириной до 5-7 м, пространственно приуроченные к местам развития трещиноватости и брекчирования пород. В этих

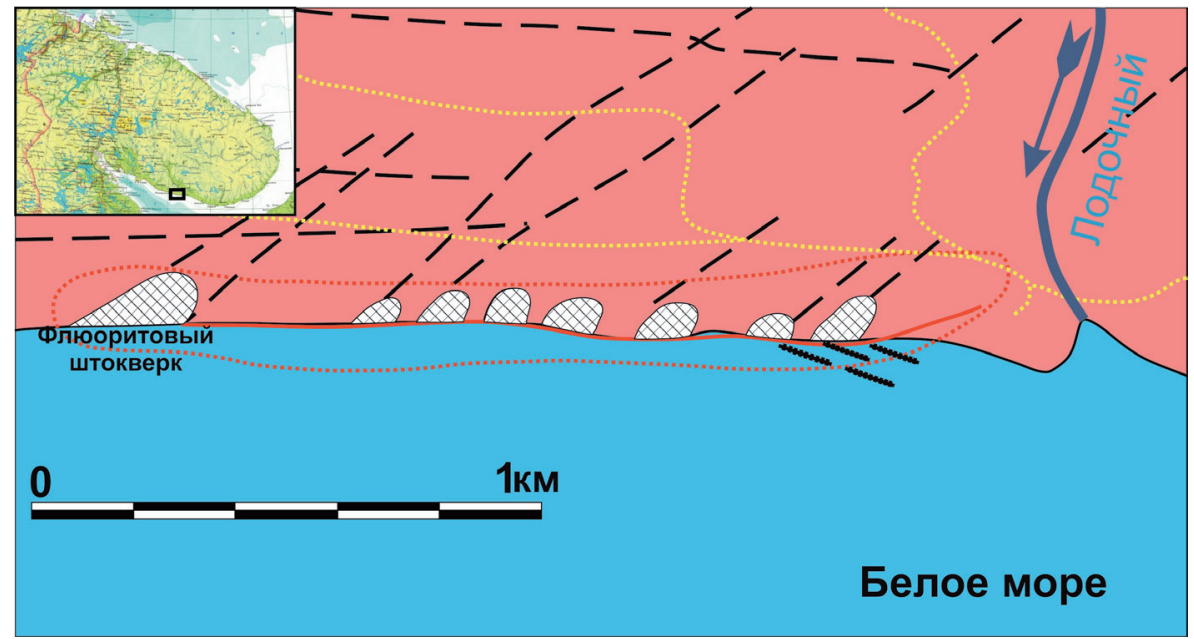

Рис. 1. Геологическая карта-схема района исследований (красное - песчаники терской свиты; косая клетка зоны гидротермальной проработки с аметистовой минерализацией; черный пунктир - тектонические разломы) и расположение жил (черные сплошные линии (вне масштаба)). Составлена с дополнениями по (Жиров и др., 2004).

Fig. 1. Geological sketch-map of the study area (red - sandstones of the Terskaya Fm; oblique cell - zones of hydrothermal alteration with fluorite mineralization; black dotted line - tectonic faults) and the location of veins (black solid lines (out of scale)). Modified after Zhirov et al. (2004). 
зонах наблюдаются многочисленные кварцевые (в том числе с аметистовой минерализацией) и баритовые жилы, флюоритовые штокверки.

\section{Характеристика вмещающих пород и околожильные изменения}

В исследуемом районе на мысе Корабль обнажаются красноцветные песчаники, алевролиты и аргиллиты. Песчаники отчетливо слоистые с параллельной, диагональной и косой слоистостью. Типичная порода представлена мелко- и среднезернистым аркозовым песчаником со средней сортировкой и пленочным железистым цементом, который локально переходит в поровый, и формировался на стадии диагенеза. Обломочная часть состоит из кварца, полевых шпатов (альбит и микроклин), акцессорных апатита, циркона, граната, титанита, магнетита и REE минералов. Зерна обломочной части в основном полуокатанные.

Песчаники вблизи контакта с жилами (до 10 см) часто брекчированы и несут признаки перераспределения первичного гематита, заключающегося в появлении сегрегаций минерала и зон лейкократизации (рис. 2). «Диагенетичекий» гематит характеризуется неправильной формой (заполняет межзерновое пространство породы), пористым строением и присутствием примесных титана, марганца и ванадия (табл. 1). Редко в околожильных песчаниках наблюдаются спутанноволокнистые округлые агрегаты (размером до $10 \mu \mathrm{m}$ ) пластинчатого гематита, по форме выделений сходного с гематитом жил (см. ниже). Характерная форма агрегатов и морфология зерен гематита указывает на их «свободный» рост в пустотах. Иногда в песчаниках развиваются сеточки тонких жилок мощностью 100-200 $\mu \mathrm{m}$, сложенных преимущественно пластинчатым гематитом. Контакты жил с вмещающими породами четкие. Характерной особенностью является развитие на экзоконтакте достаточно крупных (первые сантиметры) выделений альбита. Иногда сами контакты трассируются поздними кварцевыми прожилками мощностью до $20 \mu \mathrm{m}$, которые в свою очередь могут пересекать и сами жилы.

Таблица 1. Состав гематита (вес. \%) из вмещающего песчаника (ВП) и гематитовой жилы (ГЖ).

Table 1. Composition of hematite (wt. \%) from host sandstone (ВП) and hematite vein (ГЖ).

\begin{tabular}{|c|c|c|}
\hline Образец & ВП & ГЖ \\
\hline $\mathrm{SiO}_{2}$ & 0.47 & 0.18 \\
\hline $\mathrm{TiO}_{2}$ & 1.99 & \\
\hline $\mathrm{Al}_{2} \mathrm{O}_{3}$ & & 0.65 \\
\hline $\mathrm{Fe}_{2} \mathrm{O}_{3}$ & 93.27 & 94.63 \\
\hline $\mathrm{MnO}$ & 0.06 & \\
\hline $\mathrm{V}_{2} \mathrm{O}_{5}$ & 0.16 & \\
\hline Сумма & 95.96 & 95.46 \\
\hline
\end{tabular}

Примечание. Качественный химический анализ проводился на сканирующем электронном микроскопе Leo 1450 с энергодисперсионным анализатором Brucker X-Flash 5010 (аналитик Е.Э. Савченко, ГИ КНЦ РАН)

\section{Петрографическая характеристика жил}

Жилы состоят из мелкокристаллического (до $50 \mu \mathrm{m}$ ) пластинчатого гематита с незначительной примесью кварца и микроклина. Распределение минерала по объему жилы неравномерно. Объемное содержание минерала может составлять на отдельных участках от 30 до $100 \%$ (рис $3 \mathrm{a}, \mathrm{b}, \mathrm{c}, \mathrm{d}$ ). При увеличении содержания гематита происходит уменьшение размеров зерен, составляя в мономинеральных участках несколько микрон. Гематит второй генерации заполняет контракционные трещины и характеризуется относительно более крупным размером и правильными кристаллографическими формами (рис. $3 \mathrm{~d}, \mathrm{e}, \mathrm{g}$ ), что позволяет предполагать для него свободный рост в пустотах трещин остывания. Гематит жил характеризуется практически стехиометрическим составом (табл. 1) и не содержит примесей, характерных для «диагенетического» гематита из песчаника. Жилы могут 


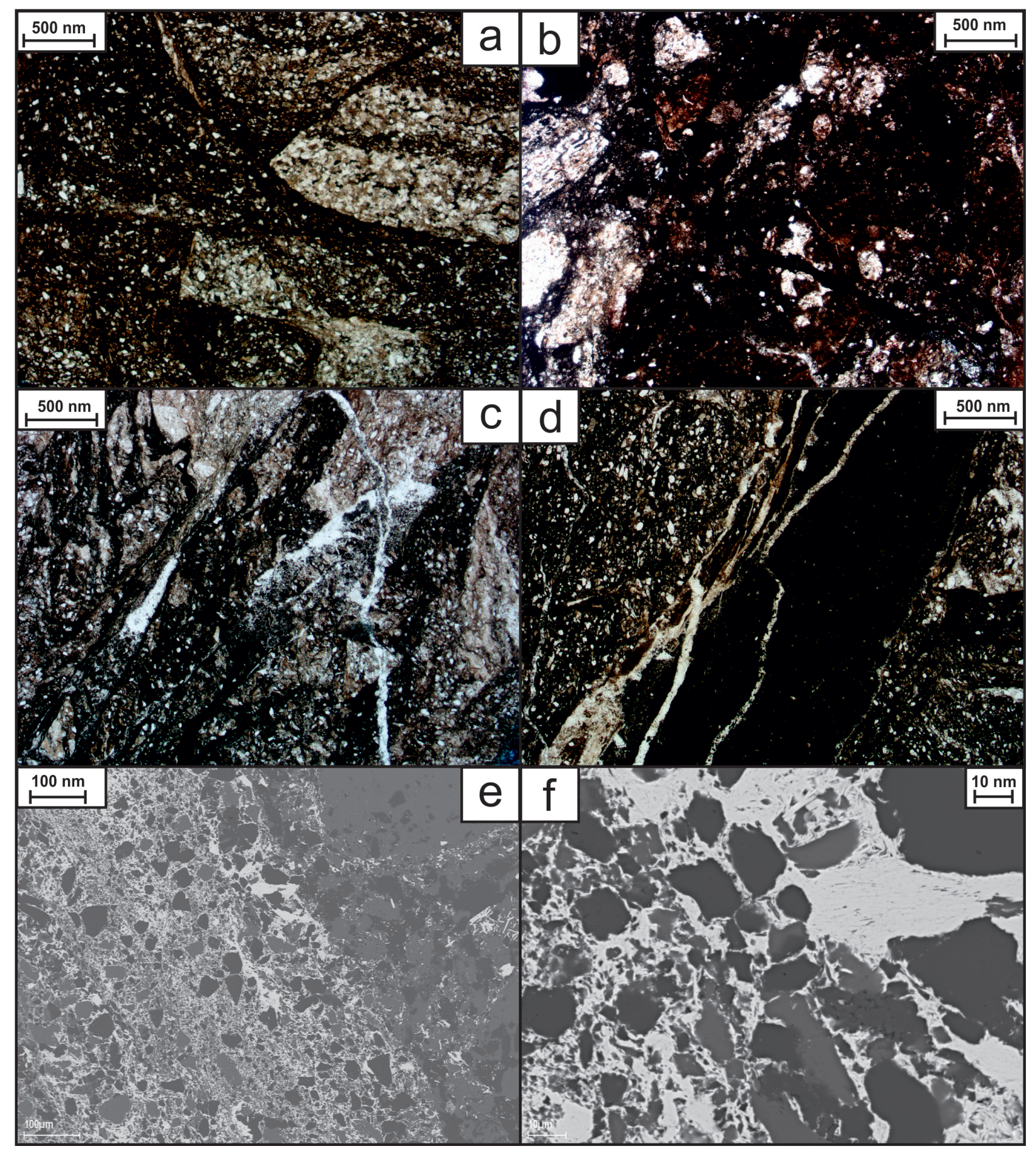

Рис. 2. Строение вмещающих пород (a - брекчирование песчаника; b - брекчии песчаников на контакте с гематитовой жилой; с - сеть тонких гематитовых жилок; d - гематитовая жилка с четкими контактами, прорывается кварцевыми жилами; е - сегрегация гематита и выделение альбита в песчанике вблизи контакта с жилой (BSE фото); f - пористое строение «диагенетического» гематита (BSE фото).

Fig. 2. The structure of the host rocks ( $\mathrm{a}$ - sandstone brecciations; $\mathrm{b}$ - sandstone breccias at the contact with a hematite vein; $\mathrm{c}$ - a network of thin hematite veins; $\mathrm{d}$ - hematite vein with clear contacts, cut by quartz veins; e - segregation of hematite and release of albite in sandstone near the contact with the vein (BSE photo), $\mathrm{f}$ - porous structure of «diagenetic» hematite (BSE photo). 


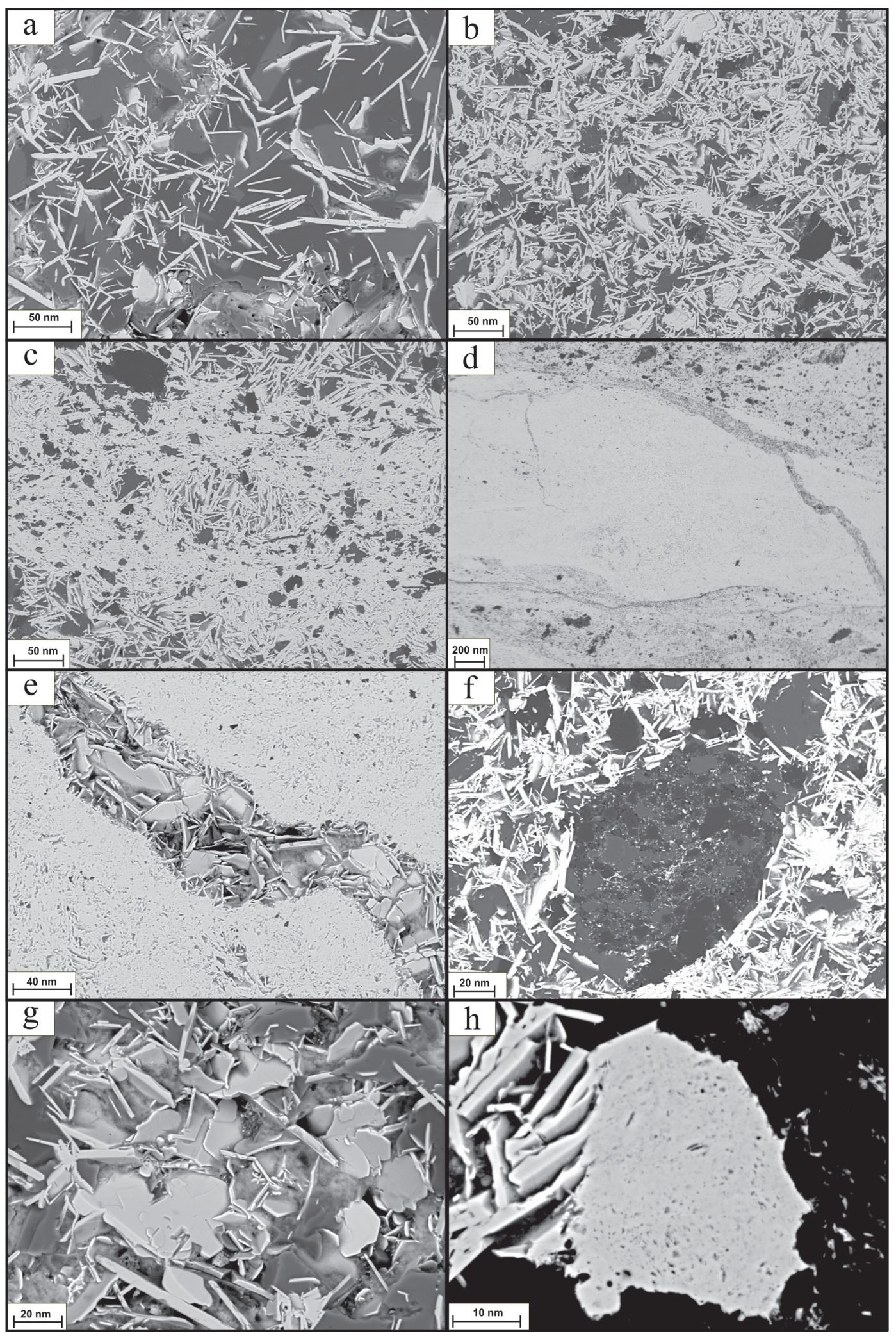

Рис. 3. Строение и минеральный состав гематитовых жил (BSE фото: a, b, c, d - морфология и распределение гематита на участках жил с разным содержанием минерала; e, g - гематит в трещинах остывания; f - ксенолит песчаника в жиле; $\mathrm{h}$ - ксеногенный «диагенетический» гематит с нарастаниями пластинок гидротермального гематита).

Fig. 3. Structure and mineral composition of hematite veins (BSE photos: a, b, c, d- morphology and distribution of hematite in parts of the veins with different mineral content; e, $\mathrm{g}$ - hematite in cooling cracks; $\mathrm{f}$ - sandstone xenolith in the vein; $\mathrm{h}$ - xenogenic «diagenetic» hematite with growths of plates of hydrothermal hematite). 
содержать обломки песчаника (рис. 3 f) и угловатые пористые ксенокристы гематита из песчаников (рис. 3 h). Для последних характерно нарастание пластинчатого гематита.

Проведенные наблюдения позволяют предположить следующую последовательность процессов при формировании жил: 1) частичное растворение первичного «диагенетического» гематита под воздействием глубинных флюидов и кристаллизация «гидротермального» гематита в порах песчаника; 2) формирование тектонических разломов, разгрузка в них рудоносного флюида и кристаллизация основной массы гематита; 3 ) формирование трещин остывания и кристаллизация в них гематита второй генерации; 4) формирование кварцевых жил.

\section{О происхождении гематитовых жил Терского берега}

Для генезиса гематитовых жил можно предположить два способа образования: гидротермальный (в этом случае необходимо предполагать существование селективно железистых гидротермальных растворов) и метасоматический (должны происходить процессы миграции железа из песчаников). По всей видимости, в формировании жил участвовали оба процесса. Гематитовые жилы имеют признаки как жил выполнения (рост минералов в свободном пространстве трещины) с резкими контактами, так и жил замещения (метасоматический рост в твердом субстрате) с неровными контактами и интенсивными околожильными измененями.

По своему составу и геологической позиции гематитовые жилы Терского берега не соответствуют ни одной категории из многочисленных вещественно-генетических формаций гидротермальных рудных месторождений (Смирнов, 1982; Авдонин, Старостин, 2010; Barnes, 1979). Но их пространственная связь с кварцевыми (аметистовыми) и баритовыми жилами, с одной стороны, и с флюоритовой минерализацией, с другой, позволяют предполагать их температурные интервалы формирования как мезотермальные $\left(350-200^{\circ} \mathrm{C}\right)$ и/или эпитермальные $\left(200-50^{\circ} \mathrm{C}\right)$. Так, для гидротермальных флюорит-гематитовых жил рудного района Шварцвальд получены температуры гомогенизации газово-жидких включений в интервале $150-155^{\circ} \mathrm{C}$ (Walter et al., 2020), а для гидротермального барит-гематитового месторождения Ахмадабад - 200-220 ${ }^{\circ} \mathrm{C}$ (Babaei, Ganji, 2018). В целом, гематитовые и кварцевые жилы с сопутствующей флюоритовой минерализацией Терского берега можно отнести к семейству флюорит-барит-кварц-карбонатных жил, образующихся в линеаментных зонах, рифтах и зонах несогласия между кристаллическим фундаментом и осадочным чехлом платформы. Классическим примером являются жилы Рейнского грабена (Walter et al., 2020), для которых показано, что основным процессом рудообразования в гидротермальных системах является смешение флюидов между горячими рассолами фундамента (или бассейновыми рассолами) и более холодными малоглубинными флюидами из осадков. В случае Терских гематитовых жил, появление глубинных флюидов связывается с палеозойской тектонотермальной реактивизацией Кандалакшского грабена и масштабным проявлением щелочно-ультраосновного магматизма в регионе.

\section{Литература}

1. Авдонин В.В., Старостин В.И. Геология полезных ископаемых. М. Изд-во: Академия. 2010. 384 с.

2. Жиров Д.В., Пожиленко В.И., Белкина О.А. и др. Терский район. СПб. Изд-во: Ника. 2004. 128 с.

3. Любцов В.В., Михайлова Н.С., Предовский А.А. Литостратиграфия и микрофоссилии позднего докембрия Кольского полуострова. Апатиты. 1989. 130 с.

4. Сергеева Э.И., Тимофеев Б.В., Сергеев А.С. Литобиостратиграфическая характеристика турьинской и терской свит // Микрофоссилии протерозоя и раннего палеозоя СССР. Л. 1974. С. 24-27.

5. Смирнов В.И. Геология полезных ископаемых. Изд. 4-е, перераб. и доп. М. Изд-во: Недра.1982. 668 с.

6. Babaei A.H., Ganji A. Characteristics of the Ahmadabad hematite/barite deposit, Iran - studies of mineralogy, geochemistry and fluid inclusions // Geologos. 2018. V. 24/1. P. 55-68.

7. Barnes H.L. (ed.) Geochemistry of Hydrothermal Ore Deposits. Wiley Interscience. New York. 1979. 798 p.

8. Walter B.F., Jensen J.L., Coutinho P., etc. Formation of hydrothermal fluorite-hematite veins by mixing of continental basement brine and redbed-derived fluid: Schwarzwald mining district, SW Germany // Journal of Geochemical Exploration. 2020. 212. 106512. 